\title{
Non-contiguous genome sequence of Mycobacterium simiae strain DSM 44165 ${ }^{\mathrm{T}}$
}

\author{
Mohamed Sassi ${ }^{1}$, Catherine Robert ${ }^{1}$, Didier Raoult ${ }^{1}$ and Michel Drancourt ${ }^{{ }^{*}}$ \\ ${ }^{1}$ Unité de Recherche sur les Maladies Infectieuses et Tropicales Emergentes (URMITE), \\ Faculté de médecine, Marseille, France
}

*Corresponding author: Professor Michel Drancourt (Michel.Drancourt@univmed.fr)

Keywords: Mycobacterium simiae draft genome, non-tuberculous mycobacteria, SOLiD

\begin{abstract}
Mycobacterium simiae is a non-tuberculosis mycobacterium causing pulmonary infections in both immunocompetent and imunocompromized patients. We announce the draft genome sequence of $M$. simiae DSM $44165^{\top}$. The 5,782,968-bp long genome with $65.15 \%$ GC content (one chromosome, no plasmid) contains 5,727 open reading frames (33\% with unknown function and 11 ORFs sizing more than 5000 -bp), three rRNA operons, 52 tRNA, one 66-bp tmRNA matching with tmRNA tags from Mycobacterium avium, Mycobacterium tuberculosis, Mycobacterium bovis, Mycobacterium microti, Mycobacterium marinum, and Mycobacterium africanum and 389 DNA repetitive sequences. Comparing ORFs and size distribution between $M$. simiae and five other Mycobacterium species $M$. simiae clustered with $M$. abscessus and M. smegmatis. A 40-kb prophage was predicted in addition to two prophagelike elements, $7-\mathrm{kb}$ and $18-\mathrm{kb}$ in size, but no mycobacteriophage was seen after the observation of $10^{6}$ M. simiae cells. Fifteen putative CRISPRs were found. Three genes were predicted to encode resistance to aminoglycosides, betalactams and macrolide-lincosamidestreptogramin B. A total of 163 CAZYmes were annotated. M. simiae contains ESX-1 to ESX-5 genes encoding for a type-VII secretion system. Availability of the genome sequence may help depict the unique properties of this environmental, opportunistic pathogen.
\end{abstract}

\section{Introduction}

Mycobacterium simiae is the type species for $M$. simiae, and is phylogenetically related to Mycobacterium triplex [1], Mycobacterium genavense [2], Mycobacterium heidelbergense [3], Mycobacterium lentiflavum [4], Mycobacterium sherrisii [5], Mycobacterium parmense [6], Mycobacterium shigaense [7], Mycobacterium stomatepiae [8] and Mycobacterium florentinum [9]. M. simiae is slow growing and photochromogenic, appearing rust-colored after exposure to light and is the only nontuberculous mycobacterium that, is niacin positive, like Mycobacterium tuberculosis [10]. M. simiae was isolated initially from rhesus macaques in 1965 [11]. In immunocompetent patients, $M$. simiae is responsible for lymphadenitis $[12,13]$, bone infection [14], respiratory tract infection [15] and skin infection [16]. M. simiae also causes infection in immunocompromized HIV-infected patients $[17,18]$, including patients with immune reconstruction [19]. Tap water has proven to be a source of $M$. simiae infection in both community and hospital-acquired infection [20,21]. To understand the genetics of $M$. simiae in detail, we sequenced and annotated a draft genome of the type strain of $M$. simiae (DSM 44165T).

\section{Classification and features}

M. simiae strain DSM $44165^{\mathrm{T}}$ is the only genome sequenced strain within the $M$. simiae complex (Table 1).

The 16S rRNA gene sequence, derived from the $M$. simiae strain DSM $44165{ }^{\mathrm{T}}$ genome sequence showed $100 \%$ sequence similarity to that of $M$. simiae type strain DSM 44165 T /ATCC 25275 T previously deposited in GenBank (GenBank accession: GQ153280.1) and 99\% sequence similarity with $M$. sherrisii (GenBank accession: AY353699.1). The $r p o B$ gene sequence of $M$. simiae showed $98 \%$ similarity with $M$. sherrisii (GenBank accession: GQ166762.1), the closest mycobacterial species. The $r p o B$ gene sequencebased phylogenetic tree (Figure 1) illustrates that M. simiae DSM $44165^{\mathrm{T}}$ is phylogentically closest to $M$. sherrisii, $M$. genavense, $M$. triplex, $M$. stomatepiae and $M$. florentinum, which are all species constituting the $M$. simiae complex. 
Table 1. Classification and general features of Mycobacterium simiae DSM44165 ${ }^{\top}$ [22].

\begin{tabular}{|c|c|c|c|}
\hline MIGS ID & Property & Term & Evidence code \\
\hline & \multirow{9}{*}{ Current classification } & Domain Bacteria & TAS [23] \\
\hline & & Phylum Actinobacteria & TAS [24] \\
\hline & & Class Actinobacteria & TAS [25] \\
\hline & & Subclass Actinobacteridae & TAS $[25,26]$ \\
\hline & & Order Actinomycetales & TAS [25-28] \\
\hline & & Suborder Corynebacterineae & TAS $[25,26]$ \\
\hline & & Family Mycobacteriaceae & TAS $[25-27,29]$ \\
\hline & & Genus Mycobacterium & TAS $[27,30,31]$ \\
\hline & & Species Mycobacterium simiae & TAS $[11,27]$ \\
\hline & Gram stain & Weakly positive & TAS [11] \\
\hline & Motility & Non motile & TAS [11] \\
\hline & Sporulation & nonsporulating & NAS \\
\hline & Temperature range & mesophile & TAS [11] \\
\hline & Optimum temperature & $37^{\circ} \mathrm{C}$ & TAS [11] \\
\hline & Salinity & normal & TAS [11] \\
\hline MIGS-22 & Oxygen requirement & aerobic & TAS [11] \\
\hline MIGS-6 & Habitat & Soil & TAS [11] \\
\hline MIGS-15 & Biotic relationship & Free-living & NAS \\
\hline \multirow[t]{3}{*}{ MIGS-14 } & Pathogenicity & none & NAS \\
\hline & Biosafety level & 2 & NAS \\
\hline & Isolation & Macacus rhesus & TAS [11] \\
\hline MIGS-4 & Geographic location & Country India & TAS [11] \\
\hline MIGS-5 & Sample collection time & 1965 & TAS [11] \\
\hline MIGS-4.1 & Latitude & 20.593684 & NAS [11] \\
\hline MIGS-4.2 & Longitude & 78.96288 & NAS [11] \\
\hline MIGS-4.3 & Depth & Not reported & TAS [11] \\
\hline MIGS-4.4 & Altitude & Not reported & TAS [11] \\
\hline
\end{tabular}

Evidence codes - TAS: Traceable Author Statement (i.e., a direct report exists in the literature); NAS: Nontraceable Author Statement (i.e., not directly observed for the living, isolated sample, but based on a generally accepted property for the species, or anecdotal evidence). These evidence codes are from the Gene Ontology project [32]. 


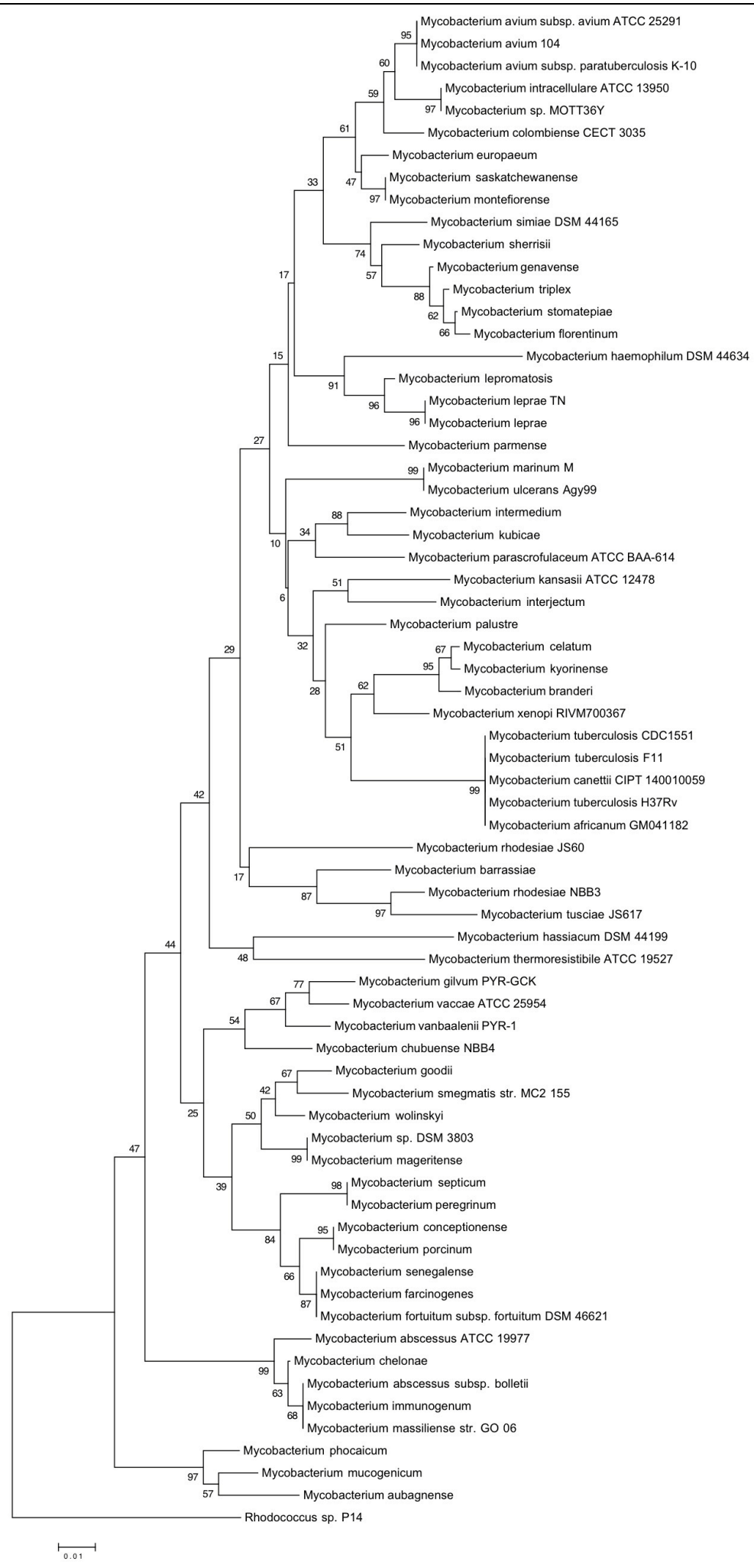

Figure 1. rpoB gene sequence based phylogenetic tree highlighting the position of Mycobacterium simiae DSM 44165 relative to other type strains within the Mycobacterium genus. Phylogenetic inferences obtained using the neighbor-joining method within MEGA. Numbers at the nodes are percentages of bootstrap values obtained by repeating the analysis 1,000 times to generate a majority consensus tree. Rhodococcus sp P14 was used as an outgroup. 
The $M$. simiae genome shares, $87 \%, 83 \%, 79 \%$ and $76 \%$ nucleotide similarity with the closest sequenced genomes of the species Mycobacterium sp: MOTT36Y (CP003491.1), $M$. intracellulare ATCC 13950 (ABIN00000000), M. indicus pranii MTCC 9506 (CP002275.1) and M. avium 104 (CP000479.1), respectively.

In order to complement the phenotypic traits previously reported for $M$. simiae [10], we observed $10^{6} \mathrm{M}$. simiae cells by electron microscopy as previously described [33]. Briefly, M. simiae cells were deposited on carbon-reinforced Formvarcoated grids and negatively stained with $1.5(\mathrm{w}: \mathrm{v})$ phosphotungstic acid (ph 7.0). The grids were examined using a Hitachi HU-12 electron microscope (FEI, Lyon, France) at $89 \times$ magnification. No phage was observed in M. simiae DSM $44165^{\mathrm{T}}$ cultures. M. simiae cells measured $1,226 \mathrm{~nm}$ in length and $594 \mathrm{~nm}$ in width of (Figure 2).

Matrix-assisted laser-desorption/ionization timeof-flight (MALDI-TOF) MS protein analysis was carried out as previously described [34]. The $M$. simiae spectra were imported into the MALDI Bio Typer software (version 2.0, Bruker,
Wissembourg, France) and analyzed by standard pattern matching (with default parameter settings) against the main spectra of 3,769 bacteria, including spectra from 79 validly named mycobacterial species used as reference data, in the Bio Typer database (updated March 15th, 2012). The method of identification includes the $\mathrm{m} / \mathrm{z}$ from 3,000 to 15,000 Da. For every spectrum, 100 peaks at most were taken into account and compared with the spectra in the database. For $M$. simiae DSM $44165^{\mathrm{T}}$, the score obtained was 1.7 , matching that of M. simiae 423-B-I-2007-BSI thus suggesting that our isolate was a member of a $M$. simiae species. We incremented our database with the spectrum from $M$. simiae DSM $44165{ }^{\mathrm{T}}$ (Figure $3)$.

\section{Genome sequencing and annotation Genome project history}

M. simiae is the first member of the $M$. simiae species complex for which a genome sequence has been completed. This organism was selected to gain understanding in the genetics of $M$. simiae complex in detail (Table 2).

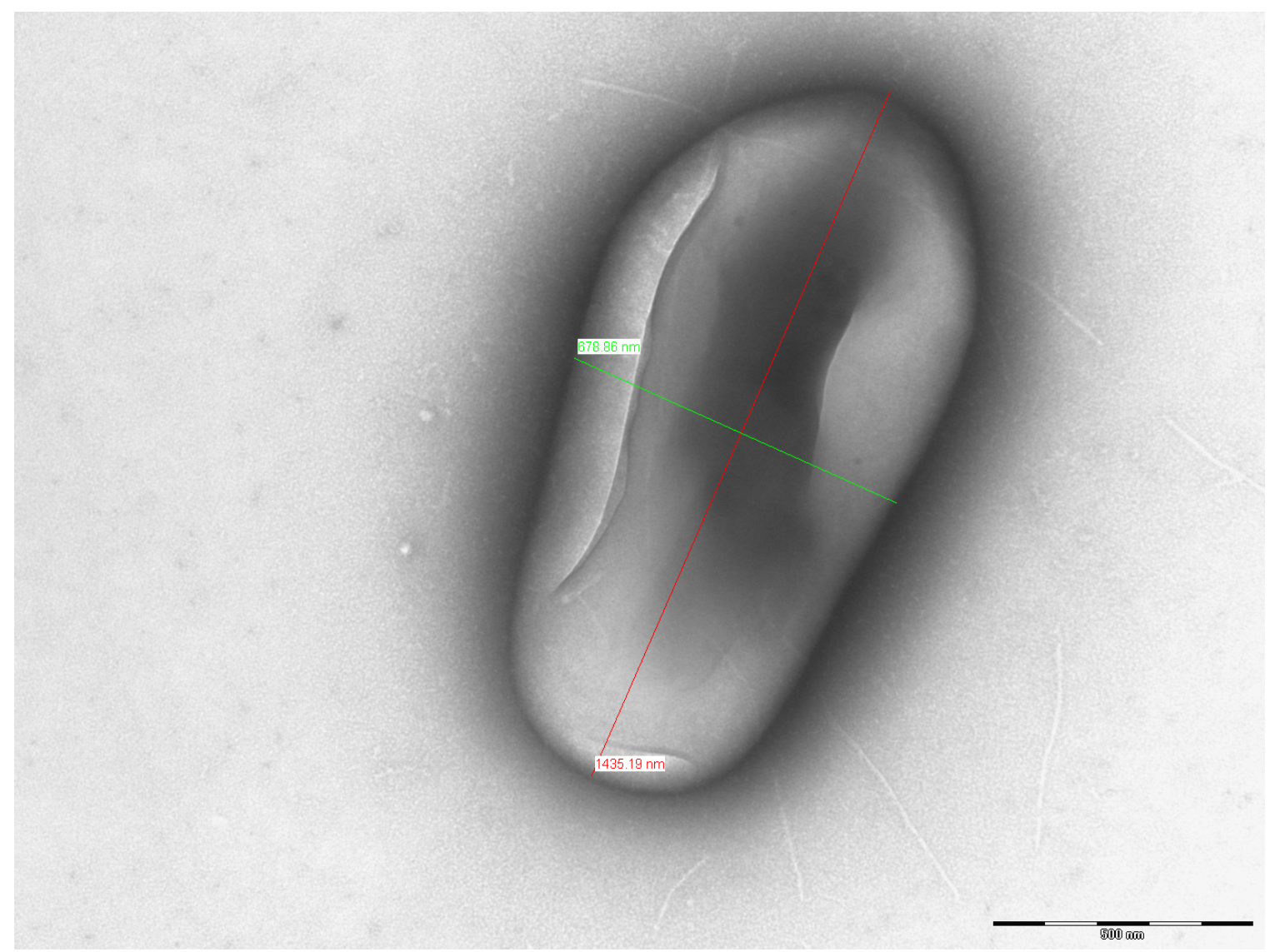

Figure 2. Electron microscopy graph of $M$. simiae DSM $44165^{\top}$ 


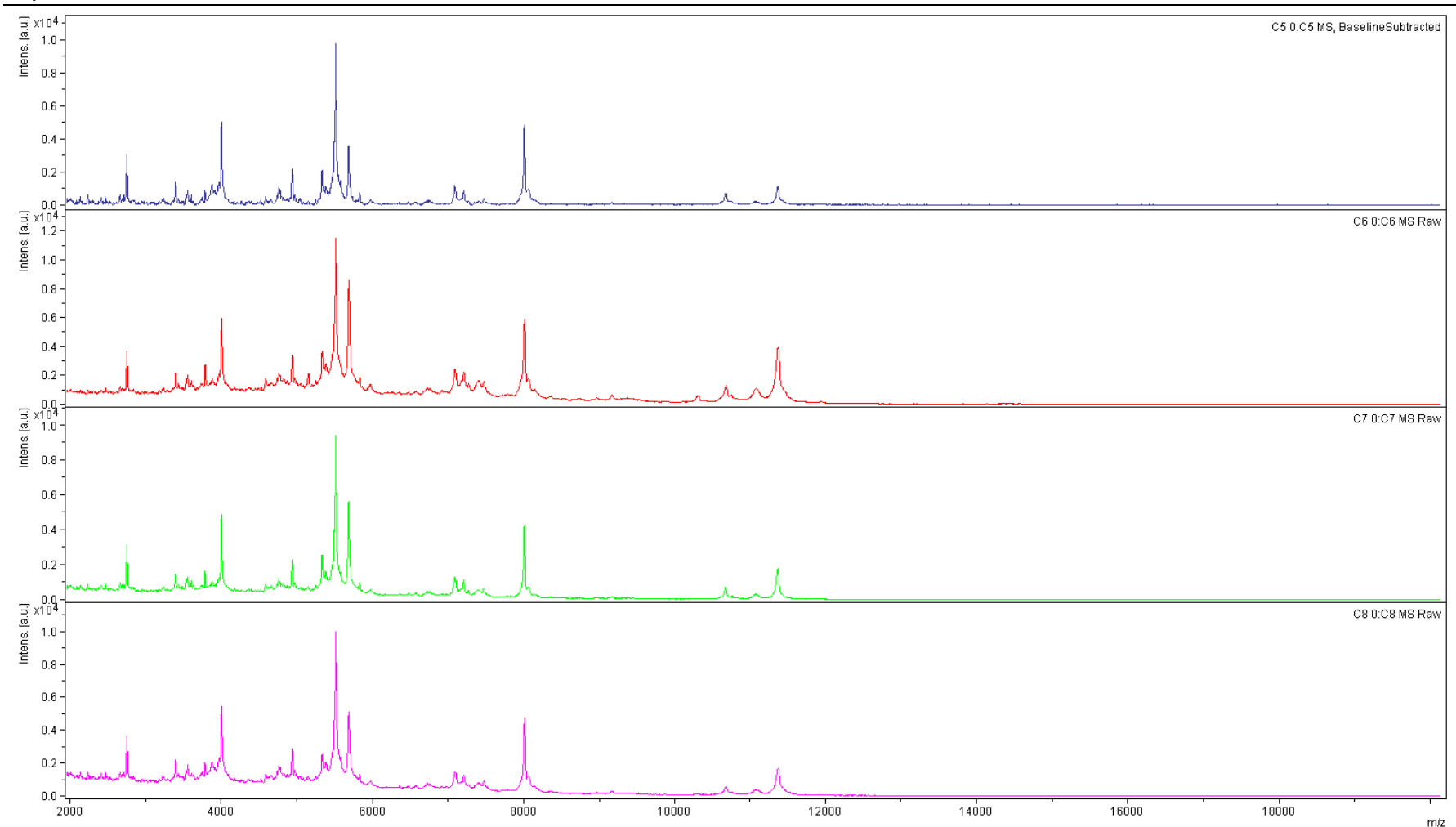

Figure 3. Reference mass spectrum from M. simiae strain DSM 44165. Spectra from 5 individual colonies were compared and a reference spectrum was generated.

Table 2. Project information

\begin{tabular}{lll}
\hline MIGS ID & Property & Term \\
\hline MIGS-31 & Finishing quality & High-quality draft \\
MIGS-28 & Libraries used & One 454 paired end 3-kb library \\
MIGS-29 & Sequencing platforms & 454 GS FLX Titanium \\
MIGS-31.2 & Fold coverage & 15.33 \\
MIGS-30 & Assemblers & Newbler version 2.5.3 \\
MIGS-32 & Gene calling method & Prodigal \\
& EMBL-EBI/NCBI project ID & PRJEB1560 \\
& EMBL-EBI/Genbank ID & CBMJ020000001-CBMJ020000359 \\
& EMBL-EBI Date of Release & June 27, 20113 \\
& Source material identifier & DSM 44165 ${ }^{\top}$ \\
& Project relevance & Pangenome of opportunistic mycobacteria \\
\hline
\end{tabular}




\section{Growth conditions and DNA isolation}

M. simiae strain DSM $44165^{\mathrm{T}}$ was grown in $7 \mathrm{H} 9$ broth (Difco, Bordeaux, France) enriched with $10 \%$ OADC (oleic acid, bovine serum albumin, dextrose and catalase) in $8-\mathrm{mL}$ tubes at $37^{\circ} \mathrm{C}$. The culture was centrifuged at $8,000 \mathrm{~g}$ for $10 \mathrm{~min}$, the pellet was resuspended in $250 \mu \mathrm{L}$ of phosphate buffered saline (PBS) and inactivated by heating at $95^{\circ} \mathrm{C}$ for one $\mathrm{h}$. The sample was then transferred into a sterile screw-cap Eppendorf tube containing $0.3 \mathrm{~g}$ of acid-washed glass beads (Sigma, SaintQuentin Fallavier, France) and shaken using a Bio 101 Fast Prep instrument (Qbiogene, Strasbourg, France) at level 6.5 (full speed) for $45 \mathrm{~s}$. The supernatant was incubated overnight at $56^{\circ} \mathrm{C}$ with $25 \mu \mathrm{L}$ proteinase $\mathrm{K}(20 \mathrm{mg} / \mathrm{ml})$ and $180 \mu \mathrm{L} \mathrm{T} 1$ buffer from the Nucleospin Tissue Mini kit (Macherey-Nagel, Hoerdt, France). After a second mechanical lysis and a 15 min incubation at $70^{\circ} \mathrm{C}$, total DNA was extracted using the NucleoSpin Tissue Mini kit (Macherey-Nagel, Hoerdt, France). The extracted DNA was eluted into $100 \mu \mathrm{L}$ of elution buffer and stored at $-20^{\circ} \mathrm{C}$ until used.

\section{Genome sequencing and assembly}

The concentration of the DNA was measured using a Quant-it Picogreen kit (Invitrogen) on the Genios Tecan fluorometer at $79.36 \mathrm{ng} / \mu \mathrm{l}$. A $5 \mu \mathrm{g}$ quantity of DNA was mechanically fragmented on the Covaris device (KBioScience-LGC Genomics, Teddington, UK) through miniTUBE-Red $5 \mathrm{~Kb}$. The DNA fragmentation was visualized in an Agilent 2100 BioAnalyzer on a DNA labchip 7500 with an optimal size of $3.57 \mathrm{~kb}$. The library was constructed according to the 454 Titanium paired end protocol (Roche, Boulogne-Billancourt, France). Circularization and nebulization were performed to generate a pattern with an optimum at $415 \mathrm{bp}$. After PCR amplification through 17 cycles followed by double size selection, the single stranded paired end library was quantified on the Quant-it Ribogreen kit (Invitrogen) on the Genios_Tecan fluorometer at $865 \mathrm{pg} / \mu \mathrm{L}$. The library concentration equivalence was calculated as $1.91 \mathrm{E}+09$ molecules/ $\mu \mathrm{L}$. The library was stocked at $-20^{\circ} \mathrm{C}$ until used. The library was clonally amplified with $0.5 \mathrm{cpb}$ in 2 emPCR reactions with the GS Titanium SV emPCR Kit (Lib-L) v2 (Roche, Boulogne-Billancourt, France). The yield of the emPCR was $20.2 \%$, which is somewhat high compared to the range of 5 to $20 \%$ from the Roche procedure. A total of 790,000 beads were loaded on the GS Titanium PicoTiterPlate PTP Kit 70x75 and sequenced with a GS Titanium Sequencing Kit
XLR70 (Roche, Boulogne-Billancourt, France). The run was done overnight and analyzed on the cluster through the gsRunBrowser and gsAssembler_Roche. A total of 241,405 passed filter wells were obtained and generated $88.64 \mathrm{Mb}$ with an average $367 \mathrm{bp}$ length. The passed filter sequences were assembled on the gsAssembler (Roche, Boulogne-Billancourt, France), with 90\% identity and $40 \mathrm{bp}$ as overlap, yielding one scaffold and 338 large contigs ( $>1,500 \mathrm{bp}$ ), generating a genome size of $5.78 \mathrm{Mb}$, which corresponds to a coverage of $15.33 \times$ genome equivalents.

\section{Genome annotation}

Open reading frames (ORFs) were predicted using Prodigal $[35,36]$ with default parameters. The predicted bacterial protein sequences were searched against the NCBI NR database, UNIPROT [37] and against COGs [38] using BLASTP. The ARAGORN software tool [39] was used to find tRNA genes, whereas ribosomal RNAs were found by using RNAmmer [40] and BLASTn against the NR database. Proteins were also checked for domain using a hidden Markov model (HMM) search against the PFAM database [41]. The Tandem Repeat Finder was used for repetitive DNA prediction [42]. The prophage region prediction was completed using PHAST (PHAge Search Tool) [43]. CRISPRs were found using the CRISPER finder [44].

The antibiotic resistance genes were annotated using. The CAZYmes, which are enzymes involved in the synthesis, metabolism, and transport of carbohydrates were annotated using CAZYmes Analysis Toolkit (CAT) (mothra.ornl.gov/cgibin/cat.cgi?tab=CAZymes)

\section{Genome properties}

M. simiae strain DSM $44165{ }^{\mathrm{T}}$ genome consists of a 5,782,968-pb long (65.15\% GC content) chromosome without plasmids (Figure 4). Table 3 presents the nucleotide content and gene count levels of the genome and the distribution of genes into COGs functional categories is presented in Table 4. The genome contains three rRNA (5S rRNA, 23S rRNA and 16S rRNA), 52 tRNA genes with one transfer-messenger RNA (tmRNA) and 5,727 ORFs with 4,673 ORFs (81.6\%) having at least one PFAM domain. The properties and the statistics of the genome are summarized in Table 3. Of the coding sequences, $66 \%$ could be assigned to COG families (Table 4). 


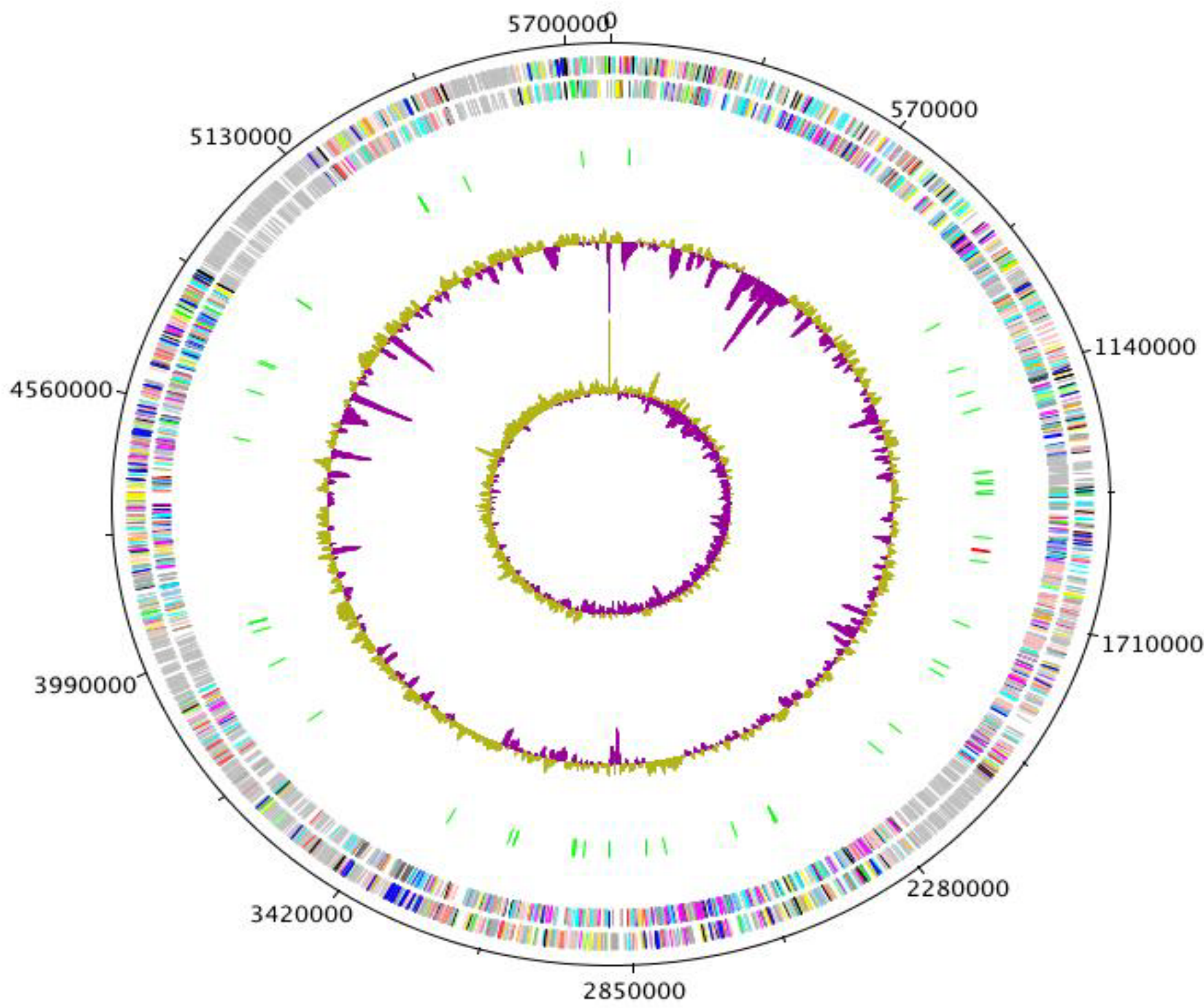

Figure 4. Graphical circular map of the chromosome. From outside to the center: Genes on the forward strand (colored by COG categories), genes on the reverse strand (colored by COG categories), RNA genes (tRNAs green, rRNAs red), GC content, and GC skew. 
Table 3. Nucleotide content and gene count levels of the genome

\begin{tabular}{lrr}
\hline Attribute & Value & \% of total $^{\mathbf{a}}$ \\
\hline Genome size (bp) & $5,782,968$ & 100 \\
DNA coding region (bp) & $5,072,379$ & 87.71 \\
DNA G+C content (bp) & $3,767,609$ & 65.15 \\
Number of replicons & 1 & \\
Extrachromosomal elements & 0 & \\
Total genes & 5,782 & 100 \\
RNA genes & 55 & 0.95 \\
Protein-coding genes & 5,727 & 99.04 \\
Genes with function prediction & 4,673 & 81.6 \\
Genes assigned to COGs & 4,105 & 71,67 \\
Genes with peptide signals & 377 & 6.58 \\
Genes with transmembrane helices & 1,144 & 19.97 \\
CRISPR repeats & 15 & \\
\hline
\end{tabular}

a) The total is based on either the size of the genome in base pairs or the total number of protein coding genes in the annotated genome

Table 4: Number of genes associated with the 25 general COG functional categories

\begin{tabular}{crrl} 
Code & Value & \% age $^{\mathbf{a}}$ & Description \\
\hline J & 157 & 2.74 & Translation \\
A & 1 & 0.02 & RNA processing and modification \\
K & 410 & 7,16 & Transcription \\
L & 171 & 2.99 & Replication, recombination and repair \\
B & 2 & 0.03 & Chromatin structure and dynamics \\
D & 34 & 0.59 & Cell cycle control, mitosis and meiosis \\
Y & 0 & 0 & Nuclear structure \\
V & 41 & 0.72 & Defense mechanisms \\
T & 169 & 2.95 & Signal transduction mechanisms \\
M & 162 & 2.83 & Cell wall/membrane biogenesis \\
N & 48 & 0.84 & Cell motility \\
Z & 0 & 0 & Cytoskeleton \\
W & 0 & 0 & Extracellular structures \\
U & 23 & 0.40 & Intracellular trafficking and secretion \\
O & 132 & 2.30 & Posttranslational modification, protein turnover, chaperones \\
C & 400 & 6.98 & Energy production and conversion \\
G & 212 & 3.70 & Carbohydrate transport and metabolism \\
E & 151 & 2.64 & Amino acid transport and metabolism \\
F & 11 & 0.19 & Nucleotide transport and metabolism \\
H & 158 & 2,76 & Coenzyme transport and metabolism \\
I & 418 & 7,30 & Lipid transport and metabolism \\
P & 192 & 3,35 & Inorganic ion transport and metabolism \\
Q & 433 & 7,56 & Secondary metabolites biosynthesis, transport and catabolism \\
R & 656 & 11,45 & General function prediction only \\
S & 291 & 5,08 & Function unknown \\
& 1622 & 1,25 & Not in COGs \\
\hline
\end{tabular}

a) The total is based on the total number of protein coding genes in the annotated genome. 
The draft $M$. simiae genome has 389 DNA repetitive sequences and contains a $40-\mathrm{kb}$ prophage like region with attachment sites. Two prophage like elements sized $7 \mathrm{~kb}$ and $8 \mathrm{~kb}$ containing six and 12 phage-like proteins respectively. A total of 15 questionable CRISPRs (Clustered Regularly Interspaced Short Palindromic Repeats) were found and three genes encoding resistance to aminoglycosides, betalactamines and MacrolideLincosamide-StreptograminB (Table 3) were annotated. M. simiae DSM $44165^{\mathrm{T}}$ showed the presence of 163 Carbohydrate-Active Enzymes genes belonging to 36 CAZy family (supplementary data S1).
Analysis of the distribution of $M$. simiae ORF size revealed $11 \mathrm{ORFs}>5,000-\mathrm{pb}$, including two ORFs $>10,000$-pb: a 12,942-bp ORF showed 77\% similarity with a $M$. avium 104 gene encoding a linear gramidicin synthase subunit D; a 14,415-bp ORF showed no similarity with NR database. We verified the open reading frames of the two ORFs using ORFs finder online software [45] and found that these ORFs encode 4,313 and 4,804 amino acids proteins respectively. A heatmap based on the distribution of ORFs sizes in M. simiae and five other genomes was done in $\mathrm{R}$ [46], which clusters M. simiae with M. abscessus and M. smegmatis, indicating that the three genomes have similar ORFs size distribution (Figure 5).
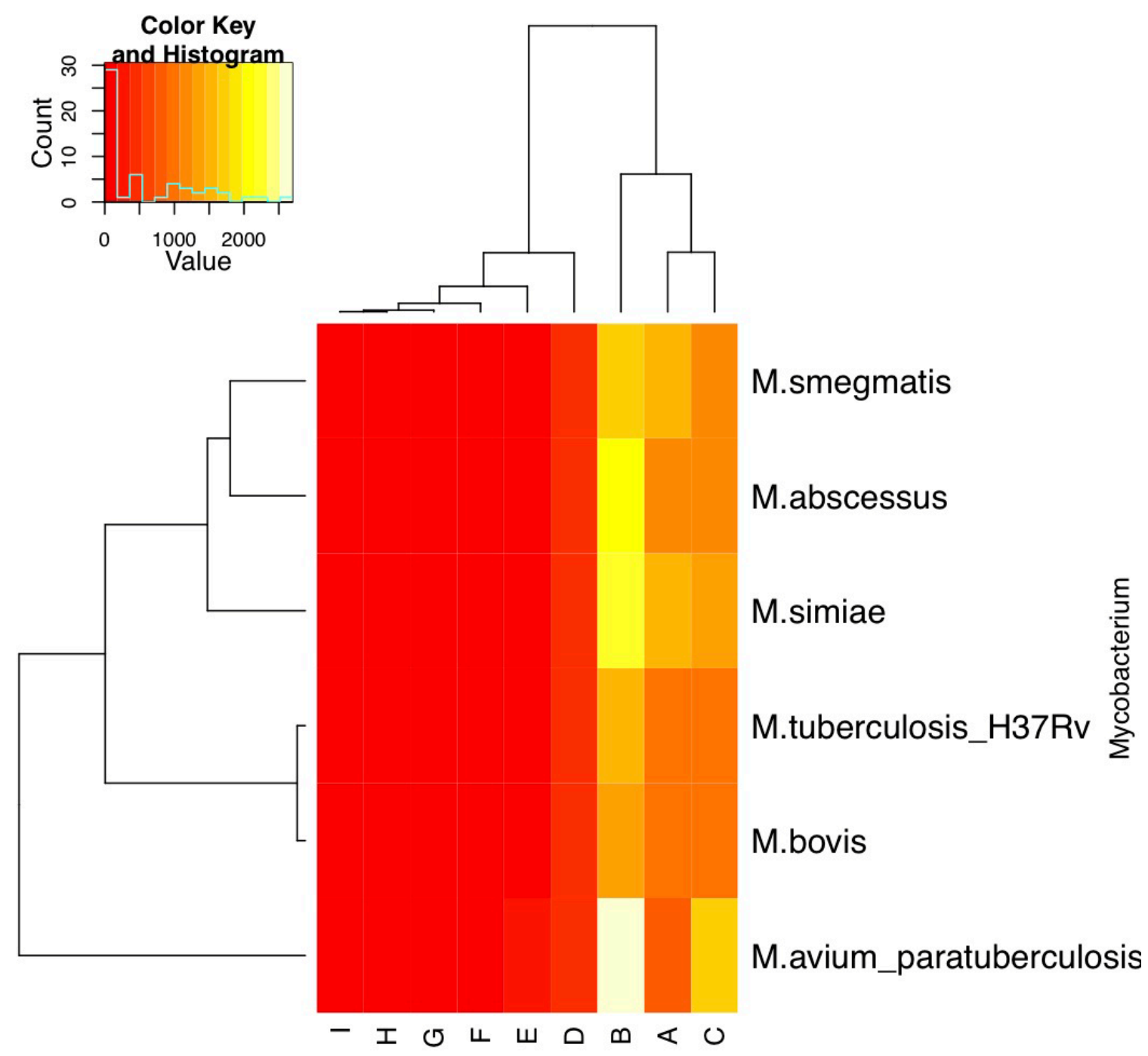

Size range

Figure 5. Heatmap of the ORFs size distribution of M. simiae compared with 5 other Mycobacterium genomes. 
Recent evidence shows that mycobacteria have developed novel and specialized secretion systems for the transport of extracellular proteins across their hydrophobic, highly impermeable, cell wall [47]. M. tuberculosis genomes encode up to five of these transport systems, and ESX-1 and ESX-5 systems are involved in virulence [47]. In

\section{Acknowledgements}

This study was supported by Unité de Recherche sur les Maladies Infectieuses et Tropicales Emergentes

\section{References}

1. Floyd MM, Guthertz LS, Silcox VA, Duffey PS, Jang Y, Desmond EP, Crawford JT, Butler WR. Characterization of an SAV organism and proposal of Mycobacterium triplex sp. nov. J Clin Microbiol 1996; 34:2963-2967. PubMed

2. Böttger EC, Hirschel B, Coyle MB. Mycobacterium genavense sp. nov. Int J Syst Bacteriol 1993; 43:841-843. PubMed http://dx.doi.org/10.1099/00207713-43-4-841

3. Pfyffer GE, Weder W, Strässle A, Russi EW. Mycobacterium heidelbergense species nov. infection mimicking a lung tumor. Clin Infect Dis 1998; 27:649-650. PubMed http://dx.doi.org/10.1086/517142

4. Springer B, Wu WK, Bodmer T, Haase G, Pfyffer GE, Kroppenstedt RM, Schröder KH, Emler S, Kilburn JO, Kirschner $\mathrm{P}$, et al. Isolation and characterization of a unique group of slowly growing mycobacteria: description of Mycobacterium lentiflavum sp. nov. J Clin Microbiol 1996; 34:1100-1107. PubMed

5. Selvarangan R, Wu WK, Nguyen TT, Carlson LD, Wallis CK, Stiglich SK, Chen YC, Jost KC, Jr., Prentice JL, Wallace RJ, Jr., et al. Characterization of a novel group of mycobacteria and proposal of Mycobacterium sherrisii sp. nov. J Clin Microbiol 2004; 42:52-59. PubMed http://dx.doi.org/10.1128/JCM.42.1.52-59.2004

6. Fanti F, Tortoli E, Hall L, Roberts GD, Kroppenstedt RM, Dodi I, Conti S, Polonelli L, Chezzi C. Mycobacterium parmense sp. nov. Int J Syst Evol Microbiol 2004; 54:1123-1127. PubMed http://dx.doi.org/10.1099/ijs.0.02760-0

7. Nakanaga K, Hoshino Y, Wakabayashi M, Fujimoto N, Tortoli E, Makino M, Tanaka T, Ishii NJ. Mycobacterium shigaense sp. nov., a novel slowly growing scotochromogenic mycobacterium that produced nodules in an erythroderma patient with severe cellular immunodeficiency and a his- comparison with $M$. tuberculosis H37Rv type VII clusters using Blastp, a total of 77 proteins encoding a type VII secretion system were annotated in M. simiae (supplementary data II). ESX-5 seems to be a conserved cluster between $M$. tuberculosis and $M$. simiae, in agreement with opportunistic pathogenicity of $M$. simiae.

(URMITE), UMR CNRS 7278, IRD 198, INSERM 1095, Faculté de Médecine, Marseille, France

tory of Hodgkin's disease. I Dermatol 2012;

39:389-396. PubMed

http://dx.doi.org/10.1111/j.1346-

$\underline{\text { 8138.2011.01355.x }}$

8. Pourahmad F, Cervellione F, Thompson KD, Taggart JB, Adams A, Richards RH. Mycobacterium stomatepiae sp. nov., a slowly growing, nonchromogenic species isolated from fish. Int J Syst Evol Microbiol 2008; 58:2821-2827. PubMed http://dx.doi.org/10.1099/ijs.0.2008/001164-0

9. Tortoli E, Rindi L, Goh KS, Katila ML, Mariottini A, Mattei R, Mazzarelli G, Suomalainen S, Torkko P, Rastogi N. Mycobacterium florentinum sp. nov., isolated from humans. Int / Syst Evol Microbiol 2005; 55:1101-1106. PubMed http://dx.doi.org/10.1099/ijs.0.63485-0

10. Rynkiewicz DL, Cage GD, Butler WR, Ampel NM. Clinical and microbiological assessment of Mycobacterium simiae isolates from a single laboratory in southern Arizona. Clin Infect Dis 1998; 26:625-630. PubMed http://dx.doi.org/10.1086/514573

11. Karassova V, Weissfeiler J, Krasznay E. Occurrence of atypical mycobacteria in Macacus rhesus. Acta Microbiol Acad Sci Hung 1965; 12:275282. PubMed

12. Patel NC, Minifee PK, Dishop MK, Munoz FM. Mycobacterium simiae cervical lymphadenitis. Pediatr Infect Dis I 2007; 26:362-363. PubMed http://dx.doi.org/10.1097/01.inf.0000258614.982 $\underline{41.4 \mathrm{e}}$

13. Cruz AT, Goytia VK, Starke J. Mycobacterium simiae complex infection in an immunocompetent child. / Clin Microbiol 2007; 45:2745-2746. PubMed http://dx.doi.org/10.1128//CM.00359-07

14. Bartanusz V, Savage JG. Destructive Mycobacterium simiae infection of the lumbar spine and retroperitoneum in an immunocompetent adult. 
Spine / 2012; 12:534-535. PubMed

http://dx.doi.org/10.1016/j.spinee.2012.05.015

15. Baghaei $P$, Tabarsi $P$, Farnia $P$, Marjani $M$, Sheikholeslami FM, Chitsaz M, Gorji Bayani P, Shamaei M, Mansouri D, Masjedi MR, et al. Pulmonary disease caused by Mycobacterium simiae in Iran's national referral center for tuberculosis. J Infect Dev Ctries 2012; 6:23-28. PubMed http://dx.doi.org/10.3855/jidc.1297

16. Piquero J, Casals VP, Higuera EL, Yakrus M, Sikes $\mathrm{D}$, de Waard JH. Iatrogenic Mycobacterium simiae skin infection in an immunocompetent patient. Emerg Infect Dis 2004; 10:969-970. PubMed http://dx.doi.org/10.3201/eid1005.030681

17. Al-Abdely HM, Revankar SG, Graybill JR. Disseminated Mycobacterium simiae infection in patients with AIDS. J Infect 2000; 41:143-147. PubMed http://dx.doi.org/10.1053/jinf.2000.0700

18. Alcalá L, Ruiz-Serrano MJ, Cosín J, GarcíaGarrote F, Ortega A, Bouza E. Disseminated infection due to Mycobacterium simiae in an AIDS patient: case report and review. Clin Microbiol Infect 1999; 5:294-296. PubMed

http://dx.doi.org/10.1111/j.14690691.1999.tb00146.x

19. Vitoria MA, González-Domínguez M, Salvo S, Crusells MJ, Letona S, Samper S, Sanjoaquín I. Mycobacterium simiae pulmonary infection unmasked during immune reconstitution in an HIV patient. Diagn Microbiol Infect Dis 2013; 75:101103. PubMed http://dx.doi.org/10.1016/j.diagmicrobio.2012.09. $\underline{004}$

20. Conger NG, O'Connell RJ, Laurel VL, Olivier KN, Graviss EA, Williams-Bouyer N, Zhang Y, BrownElliott BA, Wallace RJ, Jr. Mycobacterium simiae outbreak associated with a hospital water supply. Infect Control Hosp Epidemiol 2004; 25:10501055. PubMed http://dx.doi.org/10.1086/502342

21. El Sahly HM, Septimus E, Soini H, Septimus J, Wallace RJ, Pan X, Williams-Bouyer N, Musser JM, Graviss EA. Mycobacterium simiae pseudooutbreak resulting from a contaminated hospital water supply in Houston, Texas. Clin Infect Dis 2002; 35:802-807. PubMed http://dx.doi.org/10.1086/342331

22. Field D, Garrity G, Gray T, Morrison N, Selengut J, Sterk P, Tatusova T, Thomson N, Allen MJ, Angiuoli SV, et al. The minimum information about a genome sequence (MIGS) specification. Nat Biotechnol 2008; 26:541-547. PubMed http://dx.doi.org/10.1038/nbt1360
23. Woese CR, Kandler O, Wheelis ML. Towards a natural system of organisms: proposal for the domains Archaea, Bacteria, and Eucarya. Proc Natl Acad Sci USA 1990; 87:4576-4579. PubMed http://dx.doi.org/10.1073/pnas.87.12.4576

24. Garrity GM, Holt JG. The Road Map to the Manual. In: Garrity GM, Boone DR, Castenholz RW (eds), Bergey's Manual of Systematic Bacteriology, Second Edition, Volume 1, Springer, New York, 2001, p. 119-169.

25. Stackebrandt E, Rainey FA, Ward-Rainey NL. Proposal for a new hierarchic classification system, Actinobacteria classis nov. Int I Syst Bacteriol 1997; 47:479-491. http://dx.doi.org/10.1099/00207713-47-2-479

26. Zhi XY, Li WJ, Stackebrandt E. An update of the structure and $16 \mathrm{~S}$ rRNA gene sequence-based definition of higher ranks of the class Actinobacteria, with the proposal of two new suborders and four new families and emended descriptions of the existing higher taxa. Int / Syst Evol Microbiol 2009; 59:589-608. PubMed http://dx.doi.org/10.1099/ijs.0.65780-0

27. Skerman VBD, McGowan V, Sneath PHA. Approved Lists of Bacterial Names. Int / Syst Bacteriol 1980; 30:225-420. http://dx.doi.org/10.1099/00207713-30-1-225

28. Buchanan RE. Studies in the nomenclature and classification of bacteria. II. The primary subdivisions of the Schizomycetes. I Bacteriol 1917; 2:155-164. PubMed

29. Chester FD. Report of mycologist: bacteriological work. Delaware Agricultural Experiment Station Bulletin 1897; 9:38-145.

30. Lehmann KB, Neumann R. Atlas und Grundriss der Bakteriologie und Lehrbuch der speziellen bakteriologischen Diagnostik, First Edition, J.F. Lehmann, München, 1896, p. 1-448.

31. Runyon EH, Wayne LG, Kubica GP. Genus I. Mycobacterium Lehmann and Neumann 1896, 363. In: Buchanan RE, Gibbons NE (eds), Bergey's Manual of Determinative Bacteriology, Eighth Edition, The Williams and Wilkins Co., Baltimore, 1974, p. 682-701.

32. Ashburner M, Ball CA, Blake JA, Botstein D, Butler H, Cherry JM, Davis AP, Dolinski K, Dwight SS, Eppig JT, et al. Gene ontology: tool for the unification of biology. Nat Genet 2000; 25:25-29. PubMed http://dx.doi.org/10.1038/75556

33. Brenner S, Horne RW. A negative staining method for high resolution electron microscopy of vi- 
ruses. Biochim Biophys Acta 1959; 34:103-110. PubMed http://dx.doi.org/10.1016/00063002(59)90237-9

34. Seng P, Drancourt M, Gouriet F, La Scola B, Fournier PE, Rolain JM, Raoult D. Ongoing revolution in bacteriology: routine identification of bacteria by matrix-assisted laser desorption ionization time-of-flight mass spectrometry. Clin Infect Dis 2009; 49:543-551. PubMed http://dx.doi.org/10.1086/600885

35. Hyatt D, Chen GL, Locascio PF, Land ML, Larimer FW, Hauser LJ. Prodigal: prokaryotic gene recognition and translation initiation site identification. BMC Bioinformatics 2010; 11:119. PubMed http://dx.doi.org/10.1186/1471-2105-11-119

36. Prodigal. http://prodigal.ornl.gov/

37. UNIPROT. http://www.uniprot.org/

38. Tatusov RL, Fedorova ND, Jackson JD, Jacobs AR, Kiryutin B, Koonin EV, Krylov DM, Mazumder R, Mekhedov SL, Nikolskaya AN, et al. The COG database: an updated version includes eukaryotes. BMC Bioinformatics 2003; 4:41. PubMed http://dx.doi.org/10.1186/1471-2105-4-41

39. Laslett D, Canback B. ARAGORN, a program to detect tRNA genes and tmRNA genes in nucleotide sequences. Nucleic Acids Res 2004; 32:1116. PubMed http://dx.doi.org/10.1093/nar/gkh152

40. Lagesen K, Hallin P, Rødland EA, Staerfeldt HH, Rognes T, Ussery DW. RNAmmer: consistent and rapid annotation of ribosomal RNA genes. Nucleic Acids Res 2007; 35:3100-3108. PubMed http://dx.doi.org/10.1093/nar/gkm160

41. Punta M, Coggill PC, Eberhardt RY, Mistry J, Tate J, Boursnell C, Pang N, Forslund K, Ceric G, Clements J, et al. The Pfam protein families database. Nucleic Acids Res 2012; 40:D290-D301. PubMed http://dx.doi.org/10.1093/nar/gkr1065

42. Benson G. Tandem repeats finder: a program to analyze DNA sequences. Nucleic Acids Res 1999; 27:573-580. PubMed http://dx.doi.org/10.1093/nar/27.2.573

43. Zhou Y, Liang Y, Lynch KH, Dennis JJ, Wishart DS. PHAST: A Fast Phage Search Tool. Nucleic Acids Res 2011; 39:W347-W352. PubMed http://dx.doi.org/10.1093/nar/gkr485

44. CRISPER. http://crispr.u-psud.fr/server/

45. ORFs. http://www.ncbi.nlm.nih.gov/projects/gorf/

46. Heiberger RM, Holland B. 2004. Statistical Analysis and Data Display: An Intermediate Course with Examples in S-Plus, $R$, and SAS. Springer Texts in Statistics. Springer. ISBN 0-387-40270-5.

47. Abdallah AM, Gey van Pittius NC, Champion PA, Cox J, Luirink J, Vandenbroucke-Grauls CM, Appelmelk BJ, Bitter W. Type VII secretion-mycobacteria show the way. Nat Rev Microbiol 2007; 5:883-891. PubMed http://dx.doi.org/10.1038/nrmicro1773 